\title{
Evaluation of the snowmelt runoff model in the Moroccan High Atlas Mountains using two snow-cover estimates
}

\author{
ABDELGHANI BOUDHAR ${ }^{1}$, LAHOUCINE HANICH ${ }^{1}$, GILLES BOULET ${ }^{2}$, \\ BENOIT DUCHEMIN ${ }^{2}$, BRAHIM BERJAMY ${ }^{3} \&$ ABDELGHANI CHEHBOUNI ${ }^{2}$ \\ 1 Faculté des Sciences et Techniques de Marrakech, Avenue A. Khattabi, BP 549, Marrakech, Morocco \\ boudhar22@yahoo.fr \\ 2 CESBIO, (Université de Toulouse, CNRS, CNES, IRD), 18 Avenue Edouard Belin, bpi 2801, F-31401 Toulouse Cedex 9 , \\ France \\ 3 Agence du Bassin Hydraulique de Tensift, Marrakech, Morocco
}

\begin{abstract}
In the centre of Morocco, the High Atlas mountain range represents the most important water storage for the neighbouring arid plains through liquid and solid precipitation. In this context, we evaluated the performance of the Snowmelt Runoff Model (SRM) on the five main tributary watersheds of the High Atlas range. Due to the very low density of climate stations in the High Atlas, snowfall and snowmelt processes are difficult to monitor using meteorological data alone. In order to compensate for the lack of in situ data, snow maps are also derived from remotely-sensed data. We compared the streamflow forecasting performance when the model is driven by one or the other estimates of snow-covered area. Both estimates are generally comparable in all watersheds, and satisfactory streamflow simulations were obtained at seasonal time scales using both snow-cover products. However, significant differences can be observed for selected storms, with more accurate streamflow predictions being obtained when the remotely-sensed data are used.
\end{abstract}

Key words snow mapping; SPOT-VEGETATION; snowmelt runoff modelling; High Atlas Mountains, Morocco

\section{Evaluation du modèle Snowmelt Runoff dans le Haut Atlas marocain en utilisant deux estimations des surfaces enneigées}

Résumé Au centre du Maroc, la chaîne montagneuse du Haut Atlas constitue un véritable château d'eau pour les plaines arides avoisinantes, et ce à la fois grâce aux précipitations liquides et solides. Dans ce contexte, on a évalué la performance du modèle Snowmelt Runoff (SRM) dans les cinq principaux sous bassins versants du Haut Atlas. En raison de la très faible densité des stations climatiques dans le Haut Atlas, les processus de chute et de fonte des neiges sont difficiles à contrôler avec seulement des données météorologiques. Afin de compenser l'absence des données in situ, des cartes d'enneigement sont aussi dérivées à partir des données issues de la télédétection. Nous avons comparé la performance de SRM avec les deux types de cartes. Les surfaces enneigées déduites par ces deux méthodes sont généralement comparables dans tous les sous bassins versants, et des simulations satisfaisantes des débits ont été obtenues à l'échelle saisonnière en utilisant les deux types de surface de neige. En revanche, des différences significatives peuvent être observées pour certaines crues, avec une meilleure prévision des débits lorsque les données de la télédétection sont utilisées.

Mots clefs cartographie de neige; SPOT-VEGETATION; modélisation de la fonte de neige; Haut Atlas, Maroc

\section{INTRODUCTION}

In most arid and semi-arid regions of the world, water resources are limited, and under severe and increasing pressure due to the expanding needs of the population, tourism, industry and agriculture. Water resources are also affected by successive droughts. Several very dry years in sequence are often observed in the Mediterranean region (Cudennec et al., 2007), and their frequency could increase due to climate change (Ceballos-Barbancho et al., 2008). In these regions, mountains may obviously play an important role in the regional water balance (Pitlick 1994; Flerchinger \& Cooley, 2000; Khazaei et al., 2003; Viviroli et al., 2003), but the contribution of snow and rain to the annual and multi-annual water balance is still largely unknown. This is the case in the centre of Morocco, where the High Atlas mountain range represents the most important water resource for the neighbouring arid plains through liquid but also solid precipitation (Matthews, 1989, Chaponniere et al., 2005; Boudhar et al., 2007). Snowfall usually occurs from November to May at altitudes above $1400 \mathrm{~m}$, but the snow cover is rarely continuous: snow can fall and melt within one week. However, in the highest parts of the High Atlas range, snow is 
stored during several weeks to several months. High melting rates contribute to baseflow from late winter to early summer, which can be beneficial to agriculture.

Remote sensing observations are particularly useful for providing spatially-distributed input data for snowmelt runoff modelling (e.g. Dozier, 1989; Matson, 1991; Hall et al., 2002), and, in particular, snow-covered areas in the High Atlas mountains (Hanich et al., 2003; Chaponnière et al., 2005; Leroux, 2006; Boudhar et al., 2007). However, current satellites do not acquire cloudfree images at a satisfactory (optimally, daily) frequency, especially in mountainous regions where cloudiness is generally high. In order to compensate for the lack of continuity in remote sensing observations, additional information about snow state variables can be obtained from land surface models that are forced with surface meteorological variables (precipitation, air temperature and humidity, wind) and radiative variables (downward solar and long-wave radiation). Ideally, a system that optimally combines snow information from both remote sensing observations and modelling predictions and at the same time accounts for the limitations of each should provide estimates that are superior to those derived from either models or remote sensing alone. This method is commonly known as data assimilation (McLaughlin, 1995).

Data assimilation is a way to integrate data of different resolution and accuracy from a variety of sources with model predictions, to improve deterministic model accuracy (McLaughlin et al., 2005). It has been applied in hydrology with increasing frequency in recent years. Data assimilation is used not only to update the hydrological model states that optimally combine model outputs with observation, but also to quantify observational and hydrological model errors. Various data assimilation techniques are used in hydrological applications. Brasnett (1999) used statistical interpolation to assimilate global synoptic snow depth observations into a simple snow accumulation/snowmelt model. Sun et al. (2004) used an extended Kalman filter to assimilate synthetically generated snow water equivalent observations into a catchment-based land surface model. Andreadis \& Lettenmaier (2006) assimilated snow-covered area (SCA) estimates derived from the MODIS sensor, as well as snow depth derived from the AMSR sensor, into a macro-scale hydrological model. Clark et al. (2006) also used SCA observations as part of an ensemble Kalman filter to modify the statistical distribution of snow in a mountainous watershed. They applied a simple, lumped snowpack/water-balance model and carried out synthetic experiments that showed that SCA assimilation does not result in significant improvement of simulated streamflow. However, they acknowledge that "satellite SCA information will be most useful in basins where snow cover is ephemeral", which is the case in the High Atlas range.

The most widely used model designed to integrate SCA information directly as input is the Snowmelt Runoff Model (SRM, Martinec, 1975). This approach is equivalent to the "direct insertion" method and is very efficient when model errors are larger than observation errors. Most other approaches simulate SCA and, when a satellite observation is available, they readjust the Snow Water Equivalent (SWE) to minimize the difference between simulated and observed SCA by means of a Kalman filter (Clark et al., 2006, Slater \& Clark., 2006), or a variational assimilation scheme (Seo et al., 2003). Between two image acquisitions, they simulate the evolution of the snowpack with a snowfall/snowmelt model that uses detailed distributed meteorological data. These approaches are rather difficult to implement and perform accurately in well-instrumented catchments where observation and model errors have comparable orders of magnitude. For most mountainous regions, partly due to accessibility constraints, rainfall/snowfall and other meteorological information are often lacking, especially in the highest parts of the catchments. This is the case in the High Atlas range, where most of the meteorological stations, which routinely measure only bulk precipitation and air temperature, are located close to the catchment outlets. The more complex models and assimilation methods are likely to fail or under-perform in such poorly instrumented environments. This explains why many operational streamflow forecasting methods favour the simple and robust SRM model as well as the direct insertion method. Of course, driving models such as SRM with good SCA estimates remains a challenge in mountainous regions where spatially-distributed climatic data are lacking and where remote sensing data cannot be acquired with a sufficiently high temporal resolution. 
In this context, the first objective of this paper is to compare snow-covered area estimated by remote sensing and that simulated by spatially-interpolated meteorological data. The second objective is to test the performance of the SRM model for five sub-catchments of the High Atlas range during the years 2002-2005, and to study the impact on this performance of choosing either of the two SCA estimation methods: (1) snow depletion curves obtained from a temporal interpolation of SPOT-VEGETATION SCA estimates, and (2) a snowfall/snowmelt degree-day model forced with spatially-interpolated meteorological data.

\section{STUDY AREA}

The study area is located in the Tensift watershed in central Morocco (Fig. 1). This watershed covers $20450 \mathrm{~km}^{2}$ and comprises three parts: the northern Jbilet hills, the Haouz plain and the

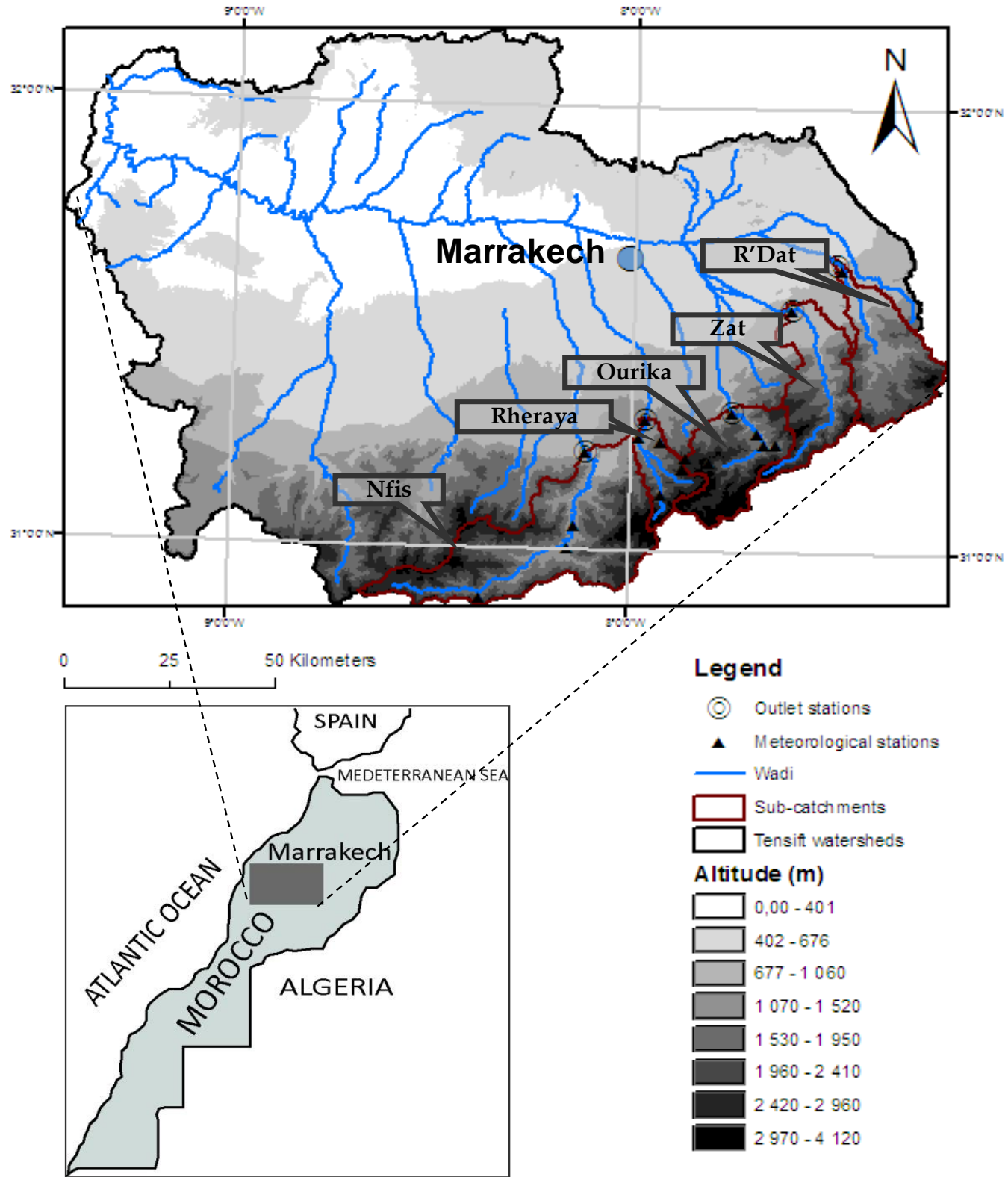

Fig. 1 Atlas sub-catchments within the Tensift watershed. 
northern side of the high Atlas Mountain range. The Tensift Wadi flows sporadically from east to west and is supplied mainly from the basin's south bank: the northern slopes of the Atlas.

The High Atlas Mountains are mainly composed of metamorphic and eruptive formations, which are impervious and generate overland flow. Some pervious zones are still present, due to calcareous and marly sandstone formations or local weathering of the impervious formations. These pervious zones are probably responsible for additional delay in lateral subsurface flow. The relief of the Atlas Mountains is very sharp with steep slopes. Land cover consists of sparse trees (coniferous and juniper) below $2000 \mathrm{~m}$ a.m.s.l., and bare rocks above. Soils are almost nonexistent on the slopes because of high erosion rates. In the very narrow valleys, where the eroded sediments accumulate, deeper soils are present, on which crops are grown. The Atlas Mountain range, about $800 \mathrm{~km}$ long and $60 \mathrm{~km}$ wide, is oriented NE-SW. The highest peak in the regionthe highest summit of North Africa-is the Jbel Toubkal (4167 m a.m.s.l.). The High Atlas range is the region's water tower, supplying several big irrigated areas in the surrounding plains of Haouz in the north, as well as Souss, Drâa and Dades in the south. In these regions, more than $85 \%$ of the available water is used for agriculture.

Located in the surroundings of the city of Marrakech (Fig. 1), the Tensift watershed was intensively monitored as a pilot site of the SUDMED programme (Chehbouni et al., 2008). The annual rainfall ranges from around $150 \mathrm{~mm}$ in the driest part of the plain to about $800 \mathrm{~mm}$ in the mountains. Both rain and snow are very irregular in time and space. There is no glacier in the area; therefore meltwater originates totally from snow.

The five main tributary sub-catchments of the Tensift watershed are located to the south and east of Marrakech, between latitudes $30^{\circ} 87^{\prime}-31^{\circ} 66^{\prime} \mathrm{N}$ and longitudes $22^{\circ} 7^{\prime}-8^{\circ} 67^{\prime} \mathrm{W}$. They form the southern boundary of the Tensift basin. They are from west to east: Nfis, Rheraya, Ourika, Zat and R'Dat (Fig. 1). To run the SRM model, the sub-catchments were subdivided into eight elevation zones. This partition was done using a digital elevation model (DEM), at 90-m spatial resolution, provided by the Shuttle Radar Topography Mission (SRTM) after an 11-day mission in February 2000. Figure 2 illustrates the hypsometric variation of the study area, and the main geographical characteristics of each sub-catchment are summarized in Table 1. The eight $400-\mathrm{m}$ elevation bands of Fig. 2 are chosen as individual hydrological response units for the SRM model.

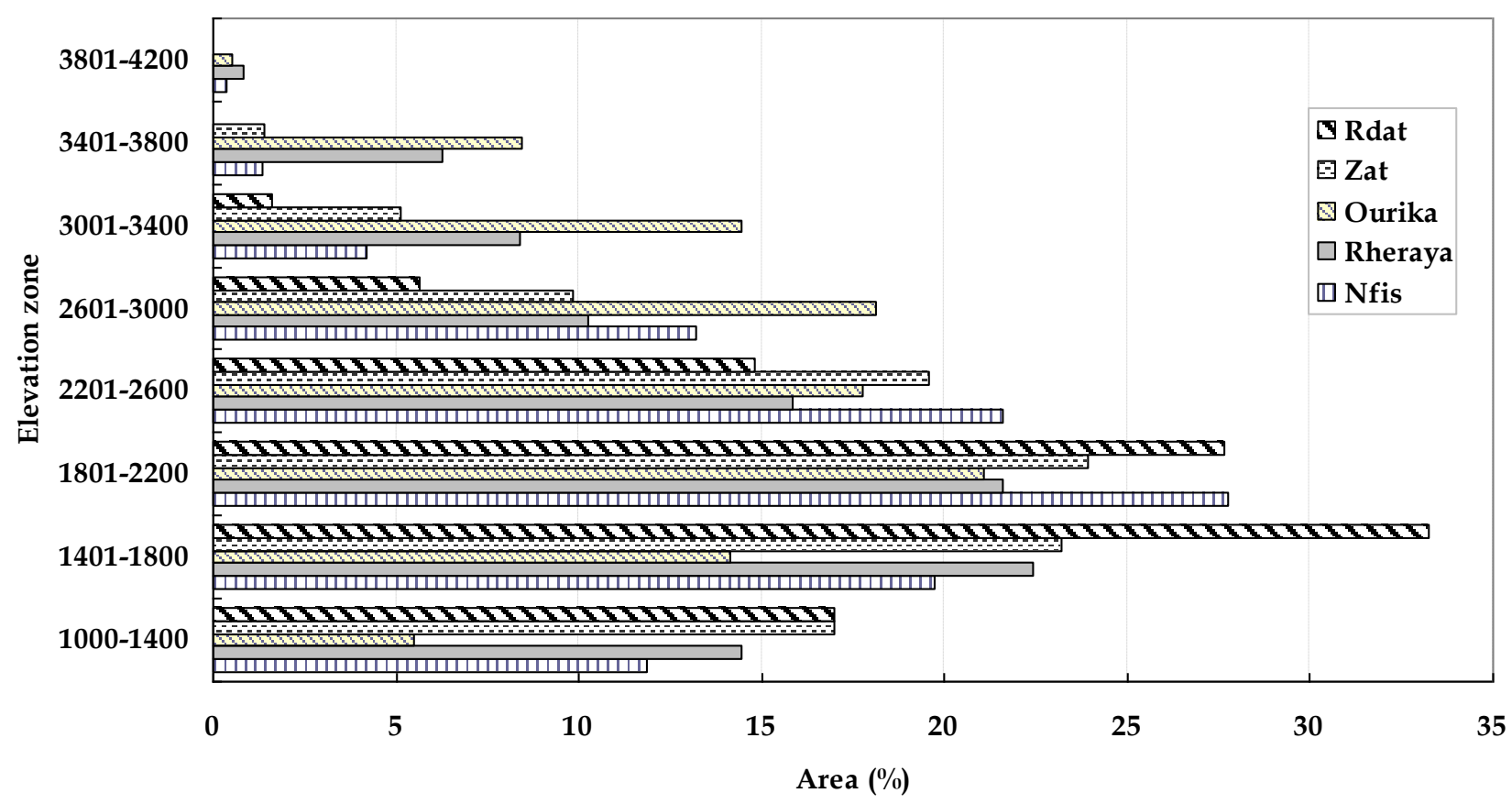

Fig. 2 Hypsometric distributions for the five study sub-catchments. 
Table 1 Geographical characteristics of the study sub-catchments.

\begin{tabular}{lcccll}
\hline Sub-catchment & $\begin{array}{l}\text { Surface area } \\
\left(\mathrm{km}^{2}\right)\end{array}$ & $\begin{array}{l}\text { Altitude }(\mathrm{m}) \\
\text { Min. }\end{array}$ & Max. & Mean & Std Dev. \\
\hline Nfis & 1288 & 750 & 4077 & 2069 & 587 \\
Rheraya & 225 & 1036 & 4117 & 2577 & 895 \\
Ourika & 507 & 974 & 3981 & 2438 & 667 \\
Zat & 540 & 720 & 3866 & 2293 & 914 \\
R'Dat & 557 & 645 & 3537 & 2091 & 840 \\
\hline
\end{tabular}

Relevant climatic input data are thus required for each of these bands. The sub-catchments can be classified in two groups: basins at high altitudes (Ourika and Rheraya) and those at lower elevations (Nfis, Zat and R'Dat).

\section{HYDROMETEOROLOGICAL DATA}

In addition to daily snow-covered area (SCA), daily estimates of air temperature and precipitation are needed to run the SRM for each altitudinal band. These data were obtained from meteorological stations in or around the five sub-catchments (Fig. 1).

For this study, daily average air temperature data recorded at the Oukaimden $(2760 \mathrm{~m})$ and Saada (411 m) weather stations over the period (1998-2005) were used to calculate a global mean lapse rate of $0.56^{\circ} \mathrm{C} / 100 \mathrm{~m}$. Mean daily temperature at each elevation zone is then obtained from the Oukaimden station data using this constant lapse rate.

To determine zonal daily precipitation, the average daily precipitation from all the available stations was assigned to the elevation band corresponding to the mean altitude of all climate stations. Daily precipitation was then extrapolated from this reference elevation band to all surrounding bands with an average observed elevation gradient of $0.03 \mathrm{~mm} / 100 \mathrm{~m}$. The latter was calculated from 1990 to 2006 between two stations: Marrakech $(450 \mathrm{~m})$ and Oukaimden $(2600 \mathrm{~m})$.

Daily runoff measurements were collected at the sub-catchment outlet stations by the regional water agency (Agence du Bassin Hydraulique de Tensift). These data were used to compare the observed and the simulated outlet hydrographs.

\section{SNOW-COVER MAPS}

\section{From remote sensing data}

Snow-covered area (SCA) maps were available at 1-km spatial resolution as a result of our previous work (Boudhar et al., 2007). The SCA maps were established from SPOT-VEGETATION blue, red and middle infrared (MIR) top-of-atmosphere reflectances (physical product, see Maisongrande $e t$ al., 2004), using the modified snow index (Chaponnière et al., 2005). The dates for which snowcover maps are available (Table 2) correspond to cloud-free conditions and limited viewing angles (view zenith angles below $23^{\circ}$ ). The mean interval between two successive clear-sky images is one week, but there are some longer periods without observations.

Table 2 Availability of SPOT-VEGETATION data and snow-cover estimates during the snowfall/snowmelt period (January-June).

\begin{tabular}{llll}
\hline Year & Number of images & $\begin{array}{l}\text { Mean interval between two } \\
\text { successive acquisitions (d) }\end{array}$ & $\begin{array}{l}\text { Max. interval between two } \\
\text { successive acquisitions (d) }\end{array}$ \\
\hline 2002 & 16 & 7 & 18 \\
2003 & 15 & 8 & 15 \\
2004 & 15 & 8 & 18 \\
2005 & 18 & 7 & 14 \\
\hline
\end{tabular}


Based on this multi-temporal data set and the DEM, the snow-covered area of each elevation zone was successively derived from each SPOT-VEGETATION snow map. Between two successive observations, depletion curves of snow coverage were interpolated at a daily step using a linear model.

\section{From meteorological data}

To estimate the daily SCA without satellite data, it is necessary to account for rainfall/snowfall partition (accumulation processes), as well as snow drift, melting and sublimation (ablation processes). For this purpose, a relationship between SCA and the snow water equivalent (SWE) was derived. The model elements consist of 30-m grid cells.

The SWE is calculated from mean daily precipitation and mean daily surface air temperature for each grid cell. Precipitation is modelled as snow if the temperature is below $0^{\circ} \mathrm{C}$; otherwise, precipitation is rain.

Snowmelt is calculated according to Makhlouf (1994) through a classical temperature index method described in Rango \& Martinec (1995):

$$
M_{s}= \begin{cases}a\left(T_{d}-T_{0}\right) & T_{d}>T_{0} \\ 0 & T_{d} \leq T_{0}\end{cases}
$$

where $M_{s}$ is the daily bulk loss of water from the snowpack (mm/unit time) and accounts for all the ablation processes; $T_{d}$ is the mean daily air temperature $\left({ }^{\circ} \mathrm{C}\right) ; T_{0}$ is the base temperature (usually, $\left.0^{\circ} \mathrm{C}\right)$; and $\alpha$ is the degree-day factor $\left(\mathrm{mm}^{\circ} \mathrm{C}^{-1} \mathrm{~d}^{-1}\right)$. The latter was computed with an empirical relationship based on snow $\left(\rho_{s}\right)$ and water $\left(\rho_{w}\right)$ densities, classically used in SRM model applications (Martinec, 1960):

$$
a=1.1 \frac{\rho_{s}}{\rho_{w}}
$$

The degree-day factor is low at the beginning of the season (fresh snow), with a general increasing trend at the end of the season, when significant snow transformation and compaction has occurred and the snowpack contains a large proportion of liquid water. In order to provide time series of snow density estimates, snow height and snow density measurements were carried out from November 2007 to March 2008 at eight locations on the upper plateau of the Oukaimden ski resort at $3200 \mathrm{~m}$ a.m.s.l. The resulting degree-day factor was averaged over each month. It varies between 2.5 and $5.0 \mathrm{~mm}^{\circ} \mathrm{C}^{-1} \mathrm{~d}^{-1}$ from November to March. The same monthly values were used to generate the SCA estimates for 2002-2005. To check whether the empirical formulation (equation (2)) is realistic for the High Atlas of Morocco, the observed degree-day factor was derived from the 2007-2008 measurement campaign for individual ablation periods. The values ranged from 0.2 (late January) to $4.7 \mathrm{~mm}^{\circ} \mathrm{C}^{-1} \mathrm{~d}^{-1}$ (late March). Due to the low space-time sampling resolution of those campaigns, we considered that the degree-day factor obtained by equation (2) was realistic, and decided to keep this model to generate SWE time series for each cell.

From the daily SWE we estimate a daily SCA using the following empirical relationship:

$$
\operatorname{SCA}(i, j)= \begin{cases}100 \% & \operatorname{SWE}(i, j) \geq 10 \mathrm{~mm} \\ 0 & \operatorname{SWE}(i, j)<10 \mathrm{~mm}\end{cases}
$$

\section{Comparison between simulated and observed SCA on the days of satellite acquisition}

Figure 3 illustrates an example of SPOT-VEGETATION and modelled snow-cover maps for four selected dates in the Rheraya sub-catchment. There is no significant difference in the spatial patterns of snow area between these two SCA estimates.

In Fig. 4, scatter plots of SCA values derived from SPOT-VEGETATION and generated by the degree-day method in all sub-catchments are shown for the period 2002-2005. The difference 

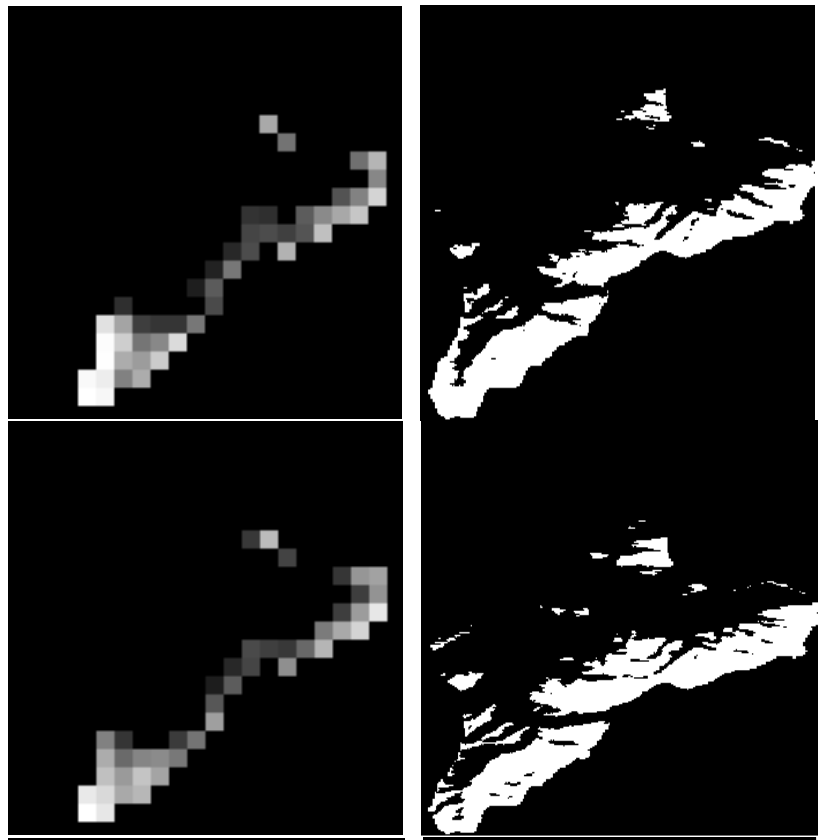

(a)
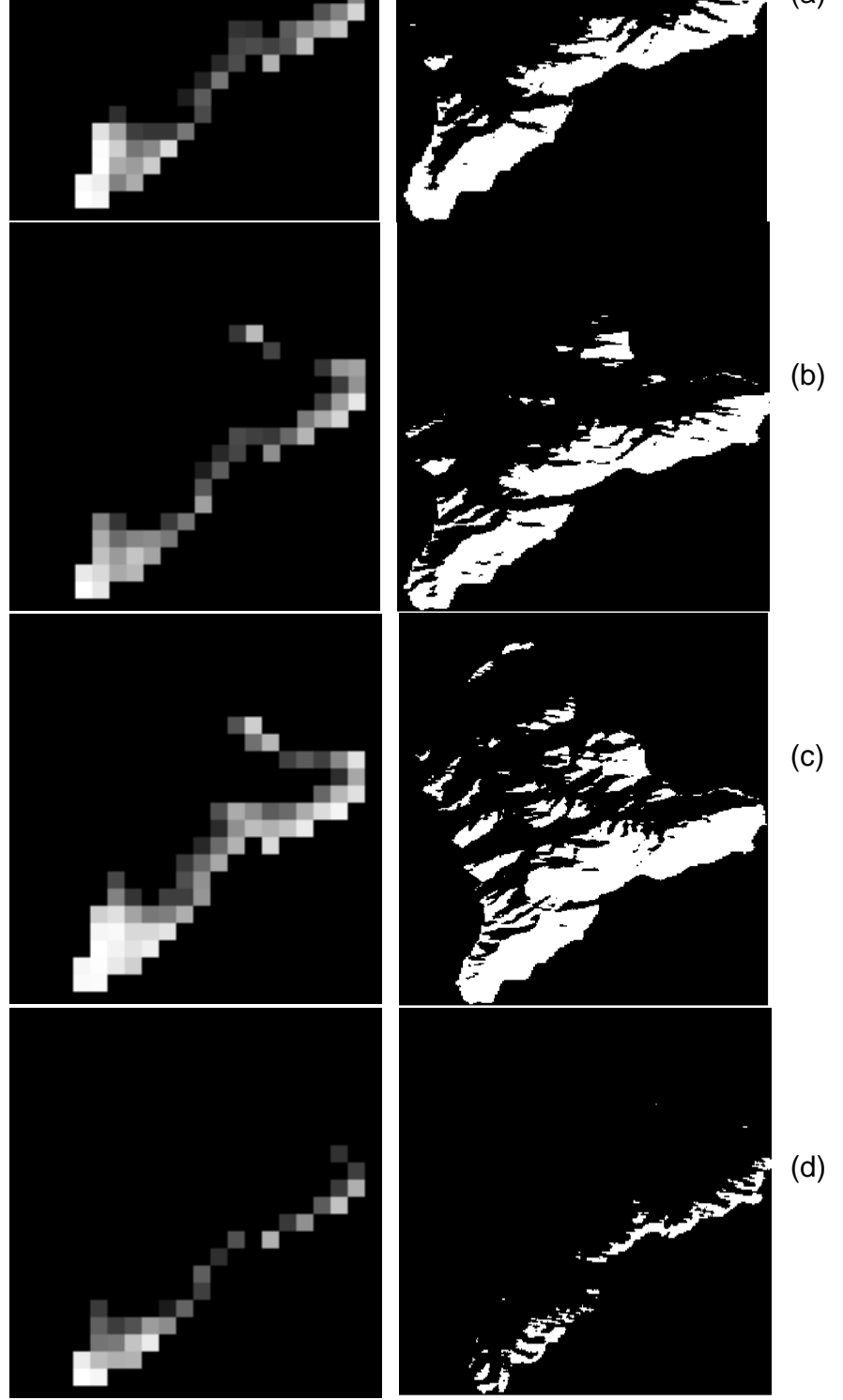

Fig. 3 Examples of snow maps derived from SPOT-VEGETATION (left), represented by grey levels (black: 0\% SCA to white: 100\% SCA), and simulated using the degree-day method (right), binary product (white: snow; black: no snow): (a) 9 January 2004; (b) 15 February 2004; (c) 16 March 2004; and (d) 18 May 2004.

between the two snow products is quantified in Table 3 using the coefficient of determination $\left(R^{2}\right)$, root mean squared error (RMSE) and Bias.

Although there is a large scatter in Fig. 4, there is little bias between observed and simulated SCA estimates for all sub-catchments, except the Ourika watershed which exhibits a small underestimation of SCA by the model (Bias $=-9 \%)$.

Globally, there is a good correlation between the two snow-cover products in all subcatchments, with an exception in 2002 when the SCA values are poorly correlated. During that drier than usual year, maximum SCA is rather small $(8,35,40,25$ and $18 \%$ of the total area in Nfis, Rheraya, Ourika, Zat and R'Dat, respectively). 

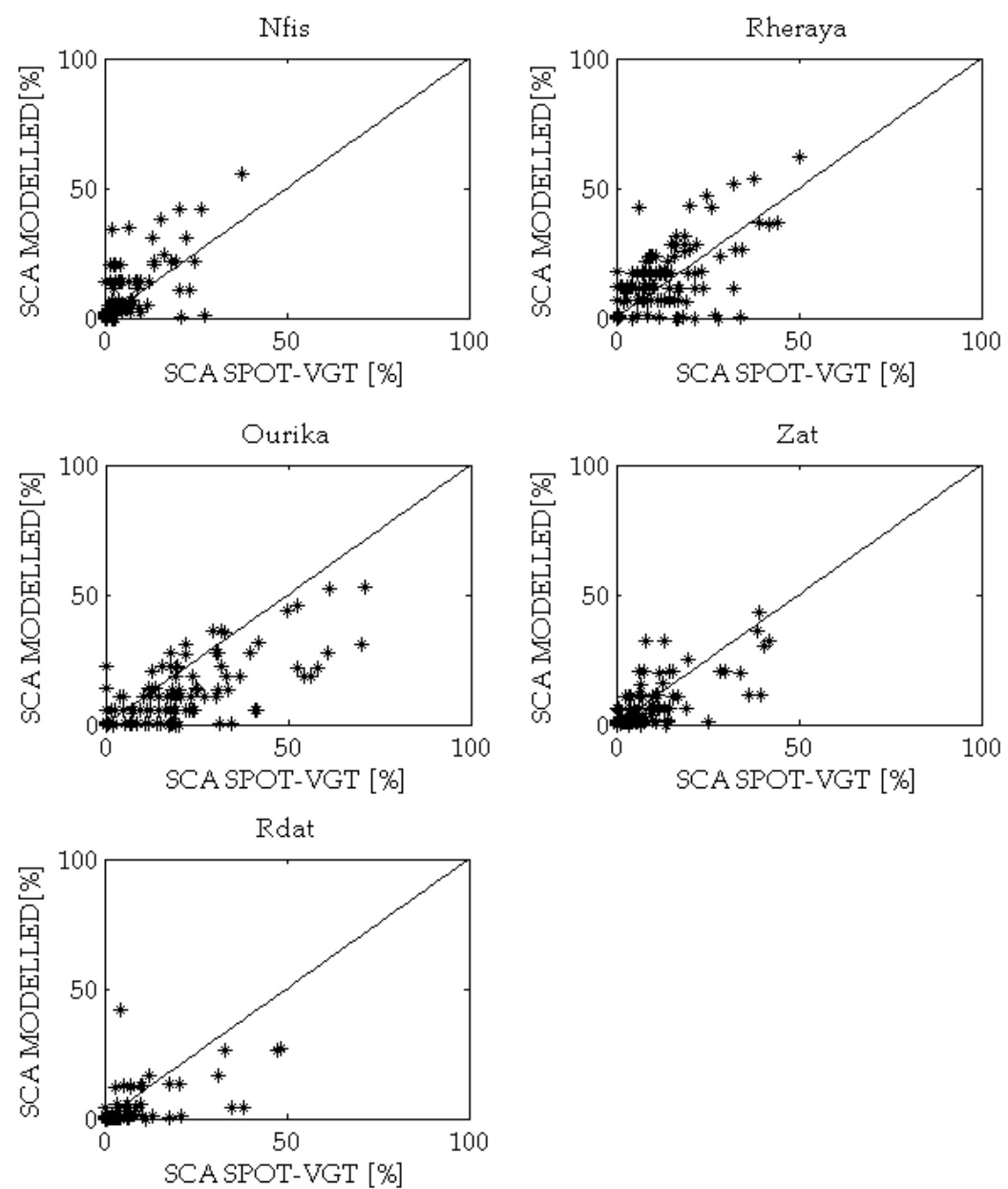

Fig. 4 Comparison between the snow-covered area calculated from SPOT-VEGETATION and that simulated by the degree-day method in five sub-catchments from 2002 to 2005.

Table 3 Comparison of statistics of the simulated vs remote sensing SCA estimates for each year and each sub-catchment.

\begin{tabular}{lllcr}
\hline & Year & $R^{2}$ & Bias $(\%)$ & RMSE (\%) \\
\hline Nfis & 2002 & 0.0 & 8.6 & 14.9 \\
& 2003 & 0.6 & 0.7 & 3.4 \\
& 2004 & 0.5 & 1.0 & 7.0 \\
\hline Rheraya & 2005 & 0.9 & -10.3 & 5.6 \\
& 2002 & 0.04 & -1.5 & 15.8 \\
& 2003 & 0.8 & 5.1 & 4.1 \\
& 2004 & 0.8 & 9.1 & 11.9 \\
\hline Ourika & 2005 & 0.8 & -9.8 & 17.8 \\
& 2002 & 0.03 & -9.6 & 13.4 \\
& 2003 & 0.8 & -7.0 & 14.2 \\
\hline Zat & 2004 & 0.6 & -1.0 & 7.0 \\
& 2005 & 0.9 & -2.0 & 8.6 \\
& 2002 & 0.02 & -2.8 & 7.6 \\
& 2003 & 0.5 & -1.9 & 5.2 \\
R'Dat & 2004 & 0.8 & 1.2 & 6.5 \\
& 2005 & 0.7 & -1.9 & 5.6 \\
& 2002 & 0.03 & -3.3 & 8.2 \\
& 2003 & 0.9 & -2.3 & 4.9 \\
\hline
\end{tabular}




\section{IMPLEMENTATION AND CALIBRATION OF SRM}

\section{Description of SRM}

Among the many snowmelt runoff models that use snow-cover information, the deterministic SRM is one of the most widely-used in both diagnostic (Rango \& van Katwijk, 1990; Songweon et al., 2005) and prognostic modes (Rango \& Martinec, 1979; Shafer et al., 1982; Martinec, 1985; Martinec \& Rango, 1995; Rango \& Martinec, 1997; Klaus, 1998; Jesko et al., 1999; Gomez \& Rango, 2002; Nagler et al., 2008). It was first applied to small European basins in 1975 and, since then, has been successfully used in approximately 80 mountainous basins in 25 countries worldwide (Martinec, 1975; Martinec et al., 2005). The SRM is a degree-day-based model for daily runoff simulation and forecasting in the mountainous areas in which snowmelt is the major runoff contributor (Rango \& Martinec, 1981; Martinec et al., 2005; Mitchell \& DeWalle, 1998). The degree-day method employed by the SRM model has been used in different ways for more than 60 years (Clyde, 1931; Collins, 1934), and Rodriguez (1994) points out that the SRM and the Hydrologiska Byrans Vattenbalansavdelning (HBV) model (Bergstrom, 1975) are the two most widely used models based on the degree-day method (Rango \& Martinec, 1995).

Assuming that there is an 18-h time lag between the meteorological inputs and the resulting streamflow, the SRM calculates the daily streamflow separately for each elevation band as follows:

$$
Q_{n+1}=\left[\mathrm{Cs}_{n} a\left(T_{n}+\Delta T\right) S_{n}+\mathrm{Cr}_{n} P_{n}\right] \frac{A \times 10000}{86400}\left(1-k_{n+1}\right)+Q_{n} k_{n+1}
$$

where the subscript $n$ denotes time in days. In equation (4), $Q_{n+1}\left(\mathrm{~m}^{3} / \mathrm{s}\right)$, the daily average discharge on day $n+1$, is calculated as the sum of three quantities from the preceding day $n$ :

- snowmelt calculated as the product of the degree-day factor a $\left(\mathrm{cm}^{\circ} \mathrm{C}^{-1} \mathrm{~d}^{-1}\right)$, the representative zonal degree-days $(T+\Delta T)\left({ }^{\circ} \mathrm{C} \mathrm{d}^{-1}\right)$, the ratio $S$ of the SCA to the total basin area $A\left(\mathrm{~km}^{2}\right)$, and the snowmelt runoff coefficient $\mathrm{Cs}$;

- precipitation contributing to runoff $(\mathrm{cm})$, calculated as the product of measured precipitation $P$ and the rainfall runoff coefficient $\mathrm{Cr}$;

- discharge on the previous day $Q_{n}$, weighted by the recession coefficient $k_{n+1}=x Q_{n}^{y}$ where $x$ and $y$ are two empirical parameters.

The term $(T+\Delta T)$ represents the extrapolated degree-day calculated at the hypsometric average elevation of the zone from the degree-days measured at the meteorological stations. The snowmelt and rainfall runoff coefficients $\mathrm{Cs}$ and $\mathrm{Cr}$ are defined, respectively, as those fractions of snowmelt and rainfall that become streamflow. The recession coefficient on day $n+1, k_{n+1}$, is defined as the ratio of streamflow on day $n+1$ to that on day $n$ when there is no input of runoff (see equation (4)). The factor $10000 / 86400$ converts $\mathrm{cm} \mathrm{km}^{2} \mathrm{~d}^{-1}$ to $\mathrm{m}^{3} / \mathrm{s}$.

Equation (4) is applied separately to each zone and the discharges are summed. In addition to the five parameters (Cs, $a, \mathrm{Cr}, x$ and $y$ ) and input data appearing in equation (1), the other parameters are the critical temperature for melting ( $\mathrm{Tf}$ ) and for the snowfall/snowmelt partition $(\mathrm{Tc})$, i.e. the temperatures, respectively, above which snow starts melting and precipitation falls as snow.

\section{Sensitivity analysis and parameters optimization}

Separate model calibration is performed for the two SCA products, i.e. that computed from SPOT VEGETATION (MOD1) and the other generated by the degree-day-method (MOD2). In order to perform a classical split-sample analysis, the year 2005 was chosen, in which relatively good hydrometeorological data are available. In contrast to other years, the measured runoff/rainfall data in 2005 are consistent and are continuously available in all sub-catchments. An automatic approach was carried out for model calibration by varying randomly each parameter value over a specified realistic searching interval (Table 4). The objective of the calibration procedure was to 
maximize the Nash \& Sutcliffe (1970) efficiency $(E)$; however, the volume error $\left(D_{V}\right)$ (i.e. mean difference between simulated and observed runoff) was also computed.

$$
\begin{aligned}
& E=1-\frac{\sum_{i=1}^{n}\left(Q_{i}-Q_{i}^{\prime}\right)^{2}}{\sum_{i=1}^{n}\left(Q_{i}-\bar{Q}\right)^{2}} \\
& D_{V}=\frac{V_{R}-V^{\prime}{ }_{R}}{V_{R}} \times 100
\end{aligned}
$$

where $Q_{i}$ is the measured daily streamflow, $Q^{\prime}{ }_{i}$ is the modelled daily streamflow and $\bar{Q}$ is the average of measured streamflow over the calibration period, $V_{R}$ is the measured cumulative streamflow volume and $V_{R}^{\prime}$ is the simulated cumulative streamflow volume.

\begin{tabular}{|c|c|c|c|c|c|}
\hline Parameters & & No. & $\begin{array}{l}\text { Value: } \\
\text { Min. }\end{array}$ & Step & Max. \\
\hline \multirow[t]{2}{*}{ Recession coefficient, $k$} & $x$ & 1 & 0.1 & 0.01 & 1 \\
\hline & $y$ & 2 & 0.01 & 0.01 & 0.1 \\
\hline Rainfall runoff coefficient, $\mathrm{Cr}$ & & 3 & 0.01 & 0.02 & 0.99 \\
\hline Snowmelt runoff coefficient, Cs & & 4 & 0.01 & 0.02 & 0.99 \\
\hline Degree-day factor, $a\left(\mathrm{~cm}^{\circ} \mathrm{C}^{-1} \mathrm{~d}^{-1}\right)$ & & 5 & 0.05 & 0.05 & 1 \\
\hline Critical temperature, $\mathrm{Tc}\left({ }^{\circ} \mathrm{C}\right)$ & & 6 & 0 & 0.2 & 6 \\
\hline Melt temperature, $\operatorname{Tf}\left({ }^{\circ} \mathrm{C}\right)$ & & 7 & 0 & 0.2 & 6 \\
\hline
\end{tabular}

Table 4 Parameter searching intervals for model calibration.

A sensitivity analysis was carried out separately for each sub-catchment to identify the most sensitive model parameters, i.e. the parameters for which $E$ varies the most when the parameter increases from the minimum to the maximum value of the searching interval. Parameters are listed in Table 4 in decreasing sensitivity order.

The variation in the efficiency, $E$, when the number of optimized parameters increases was also investigated. The adopted iterative approach consists of: (a) optimizing the most sensitive parameter first and fixing the other six parameters to values corresponding to the middle of the realistic ranges given in Table 4, and plotting the resulting Nash-Sutcliffe efficiency, $E$; then (b) optimizing the two most sensitive parameters and fixing the other five, again plotting $E$, and (c) repeating this operation for each parameter in decreasing sensitivity order until all seven parameters are optimized. An example for the Rheraya sub-catchment is illustrated in Fig. 5 for MOD1 and MOD2. In order to quantify the importance of the snowfall/snowmelt processes in the modelling performance, $E$ was also computed when all precipitation falls as snow (i.e. SCA $=0$ for all elevation bands). The graphs indicate that the performance increases rapidly when the number of parameters increases from one $(x)$ to three $(x, y, \mathrm{Cr})$. The Nash-Sutcliffe function varied from 0.33 to 0.84 in MOD1, from 0.22 to 0.75 in MOD2 and from 0.12 to 0.69 in the simulation without snow cover. The overall maximum $E$ value in the latter case is 0.69 , since there are only three parameters in the model without the snow module. Whereas for MOD2 a fourth (Cs) and fifth parameter $(a)$ still bring some improvement, the first-guess values of the snow module parameters are sufficient for the MOD1 configuration. This means that the first-guess values of $a$, $\mathrm{Tf}$ and Tc provide a reasonable estimate of the daily melting quantities for a given remotely-sensed SCA. Performances in both configurations then reach a plateau when the sixth (Tc) and seventh (Tf) parameters are calibrated, showing no significant gain. 


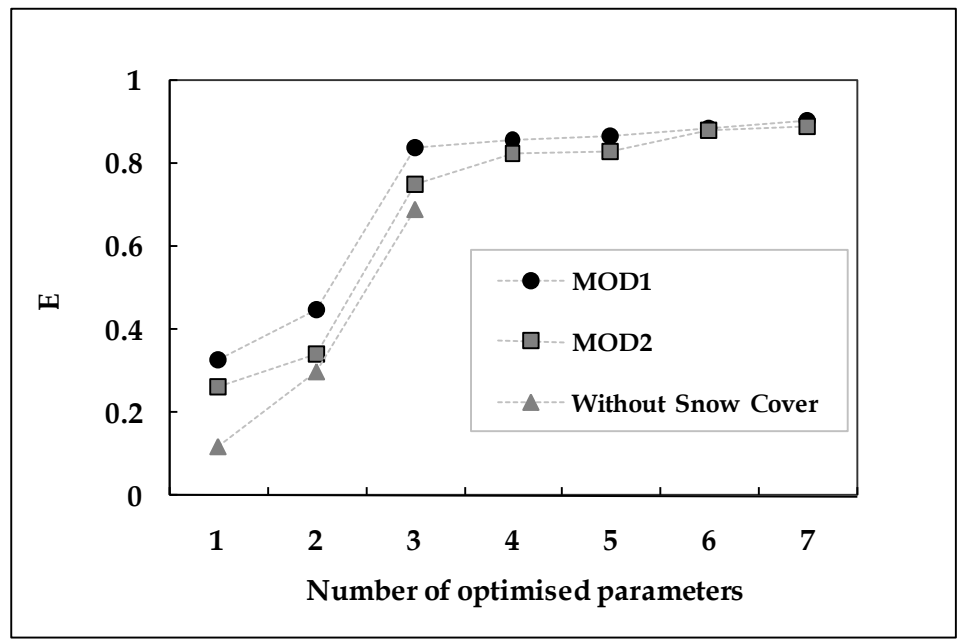

Fig. 5 Variation of the Nash-Sutcliffe efficiency, $E$, according to the number of optimized parameters using VEGETATION snow maps (MOD1), generated snow maps (MOD2) and when SCA is artificially kept as zero.

\section{Analysis of the interdependence of the model parameters}

The traditional concept of model calibration is built on the hypothesis that a unique optimum set of parameter values exists; however, there is a multitude of parameter combinations that are "equally good" for a particular objective. In most rainfall-runoff modelling exercises, calibration is performed on the only observation that is available, i.e. streamflow at the outlet. Streamflow integrates the various interactions between the different intermediate storage, loss and redistribution processes. The relative intensity of each of these processes is usually poorly known, and a satisfying match between the observed and simulated streamflow can be achieved for a large range of parameters values. Beven \& Binley (1992), Beven (1993, 2008) call this the "equifinality issue". This means that, for instance, a low value for one parameter that positively affects one redistribution process (e.g. surface runoff) combined with a high value of a second parameter governing a second redistribution process (e.g. subsurface flow) will give a value for the performance criteria that is similar to that obtained with a higher value of the first parameter combined with a lower value of the second one. The resulting parameter values deemed as "acceptable" can span a very large range of values in the solution ensemble, even within realistic boundaries. A method to check whether such an equifinality problem exists is to produce the contour plot of the Nash-Sutcliffe performance criteria for all pairs of parameters. If two parameters can be calibrated independently, the resulting contour plot peaks around one solution couple. This is the case for the $\mathrm{Cr}$ and Cs parameters of SRM in the MOD2 configuration (Fig. 6(a)) and, to a lesser extent, in MOD1, even though both parameters contribute to surface runoff. The same conclusion can be drawn for the $\mathrm{Cr}$ and degree-day factor parameters (Fig. 6(b)). If the contour lines are either horizontal or vertical, one of the two parameters is rather insensitive to streamflow prediction. This is the case for the critical temperature that initiates melting (Fig. 6(c)). If the contour lines are organized diagonally, parameter dependence is high and the two parameters cannot be calibrated independently. This is partly the case for the $x$ and $y$ parameters that govern the recession (Fig. 6(d)).

Because the SRM model is rather simple and parsimonious, equifinality is limited to the examples discussed above. After analysis of Fig. 5, we conclude that only $T_{\text {melt }}$ could be fixed at an arbitrary value, and that a narrow optimum range can be found for most parameters. Because the Nash-Sutcliffe criterion $(E)$ reaches a plateau when the less sensitive parameters are successively calibrated, we decided to retain as "acceptable" all the parameter sets that produce a value of $E$ above $90 \%$ of the overall maximum. These parameter sets will be used to generate an ensemble of 
MOD1
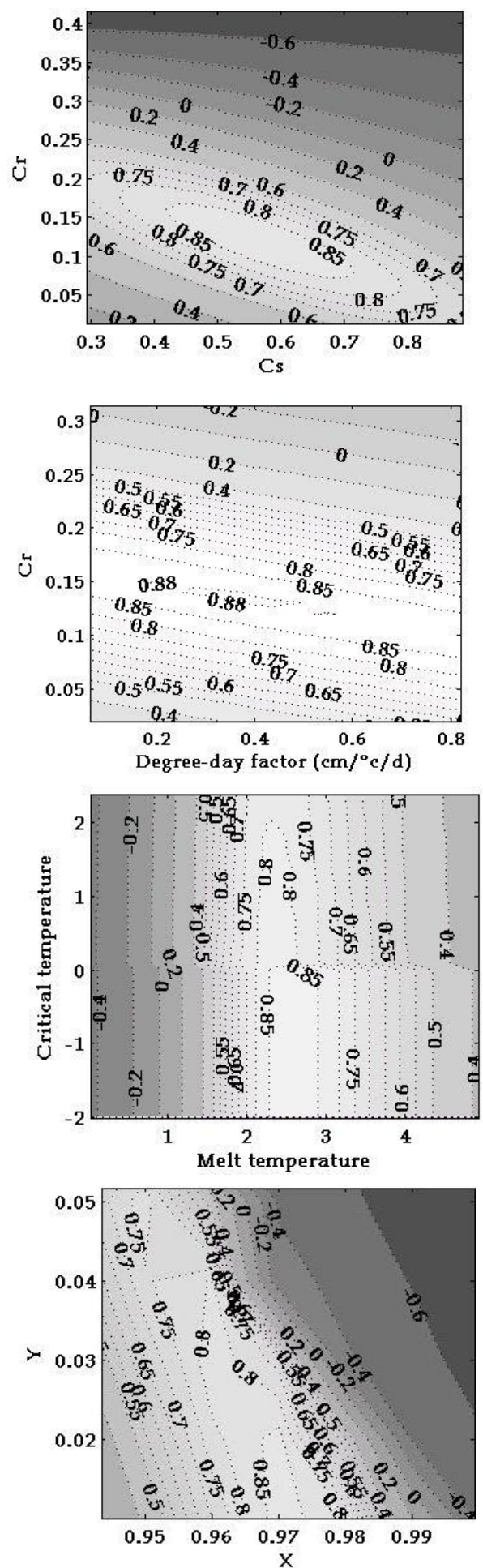

MOD2
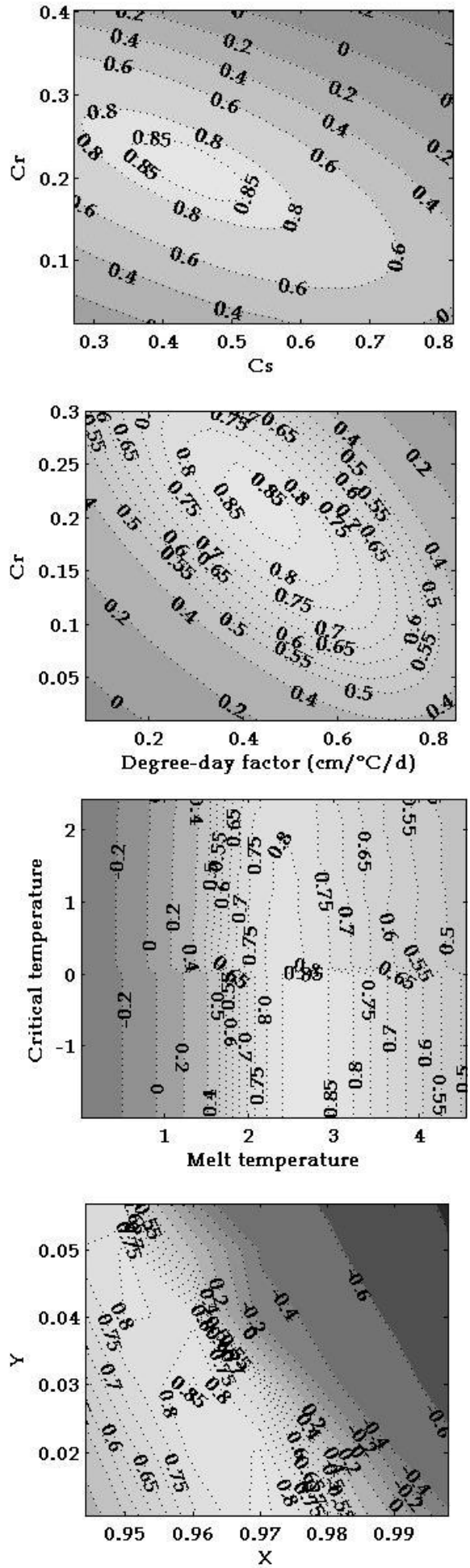

Fig. 6 Variations of $E$ depending on the model parameters (2D analysis). The model is driven by snow maps derived from SPOT-VEGETATION (MOD1, left) and simulated using the degree-day method (MOD2, right). 
Table 5 Range of optimal model parameters giving $90 \%$ of the overall maximum of Nash-Sutcliffe efficiency.

\begin{tabular}{llllllll}
\hline & $K$ & & $\mathrm{Cr}$ & $\mathrm{Cs}$ & $\begin{array}{l}a \\
\left(\mathrm{~cm}{ }^{\circ} \mathrm{C}^{-1} \mathrm{~d}^{-1}\right)\end{array}$ & $\begin{array}{l}\mathrm{Tf} \\
\left({ }^{\circ} \mathrm{C}\right)\end{array}$ & $\begin{array}{l}\mathrm{Tc} \\
\left({ }^{\circ} \mathrm{C}\right)\end{array}$ \\
\hline MOD1: & & $y$ & & & & & \\
Nfis & 0.99 & 0.02 & $0.35-0.5$ & $0.2-0.5$ & $0.2-0.6$ & $2.20-3 . .2$ & -2.0 \\
Rheraya & 0.97 & $0.01-0.02$ & $0.1-0.2$ & $0.45-0.7$ & $0.2-0.6$ & $2.20-3 . .2$ & -2.0 \\
Ourika & 0.98 & 0.02 & $0.4-0.6$ & $0.5-0.7$ & $0.2-0.6$ & $2.20-3.2$ & -2.0 \\
Zat & 0.99 & $0.03-0.04$ & $0.22-0.34$ & $0.18-0.4$ & $0.2-0.6$ & $2.20-3 . .2$ & -2.0 \\
R'Dat & 0.95 & $0.06-0.1$ & $0.22-0.3$ & $0.1-0.2$ & $0.2-0.6$ & $2.20-3.2$ & -2.0 \\
\hline MOD2: & & & & & & & \\
Nfis & 0.99 & 0.03 & $0.2-0.4$ & $0.3-0.6$ & $0.4-0.6$ & $2.20-3 . .2$ & -2.0 \\
Rheraya & 0.97 & $0.01-0.02$ & $0.18-0.24$ & $0.38-0.5$ & $0.4-0.6$ & $2.20-3 . .2$ & -2.0 \\
Ourika & 0.98 & 0.02 & $0.5-0.7$ & $0.54-0.7$ & $0.4-0.6$ & $2.20-3 . .2$ & -2.0 \\
Zat & 0.99 & $0.03-0.04$ & $0.28-0.38$ & $0.28-0.4$ & $0.4-0.6$ & $2.20-3.2$ & -2.0 \\
R'Dat & 0.95 & $0.08-0.1$ & $0.24-0.32$ & $0.1-0.3$ & $0.4-0.6$ & $2.20-3 . .2$ & -2.0 \\
\hline
\end{tabular}

streamflow time series in the validation period for each model configuration (MOD1 or MOD2). The ranges of model parameters of these subsets are shown in Table 5. Because (a) streamflow is not that sensitive to the parameter values of the snowmelt processes and (b) we expect that the climate is less variable from one sub-catchment to the next than the lateral redistribution of rain and meltwater, the model parameters related to temperature $(a, \mathrm{Tf}$ and $\mathrm{Tc})$ are considered to be the same for the five sub-catchments, while the parameters generating runoff or recession are catchment-dependent.

As expected, the calibrated values for the parameters that govern runoff or the redistribution of water are more variable from one catchment to another than from one configuration to another. Performance of the model during the calibration period (1 January-31 May 2005) shows good efficiency for the Nfis, Rheraya and Ourika sub-catchments, with $E>0.79$ for MOD1 and $E>0.70$ for MOD2 (Table 6), and satisfactory efficiency for the Zat and R'dat sub-catchments, with $E>0.63$ and $E>0.68$ for MOD1 and MOD2, respectively.

Table 6 Statistics associated with streamflow simulations (see equations (5) and (6) for definitions).

\begin{tabular}{|c|c|c|c|c|c|}
\hline & & MOD1 & & MOD2 & \\
\hline & & $D_{V}(\%)$ & $E$ & $D_{V}(\%)$ & $E$ \\
\hline Nfis & 2002 & -12.00 & 0.60 & -5.36 & 0.53 \\
\hline & 2003 & -8.97 & 0.18 & 4.04 & 0.15 \\
\hline & 2004 & 10.80 & 0.24 & 12.00 & 0.28 \\
\hline & 2005 & 2.04 & 0.79 & 2.42 & 0.70 \\
\hline Rheraya & 2002 & -23.50 & 0.67 & -2.08 & 0.54 \\
\hline & 2003 & -6.04 & 0.53 & -36.72 & -0.71 \\
\hline & 2004 & -0.18 & 0.86 & -2.93 & 0.80 \\
\hline & 2005 & 4.29 & 0.88 & 1.06 & 0.87 \\
\hline Ourika & 2002 & -14.00 & 0.71 & 17.80 & 0.54 \\
\hline & 2003 & -9.30 & 0.29 & 7.04 & -0.19 \\
\hline & 2004 & 0.69 & 0.79 & 9.64 & 0.72 \\
\hline & 2005 & 2.30 & 0.85 & 0.31 & 0.76 \\
\hline Zat & 2002 & -1.40 & 0.69 & 39.00 & 0.47 \\
\hline & 2003 & -4.60 & 0.21 & -4.54 & 0.22 \\
\hline & 2004 & 6.63 & 0.55 & 6.91 & 0.50 \\
\hline & 2005 & 13.00 & 0.63 & 14.29 & 0.68 \\
\hline R'Dat & 2002 & -45.00 & 0.64 & -43.00 & 0.64 \\
\hline & 2003 & -41.00 & 0.52 & -36.00 & 0.56 \\
\hline & 2004 & 2.48 & 0.34 & -1.90 & 0.35 \\
\hline & 2005 & -37.00 & 0.66 & -34.00 & 0.68 \\
\hline
\end{tabular}




\section{Snowmelt contribution to streamflow}

Once the SRM model is calibrated against streamflow observations, it is interesting to look at the computed meltwater production and, thus, at the relative contribution of snowmelt to streamflow. In this exercise, the snow extents computed from SPOT-VEGETATION are used. The relative contributions of snowmelt and rainfall are summarized in Table 7 for each sub-catchment between 2002 and 2005. In line with the inter-annual and inter-basin variability in observed snow-covered area, the fractions of snowmelt contributing to streamflow are also variable from one year to another and from one sub-catchment to another. Except for 2005, where snowmelt contributes significantly in all sub-catchments (varying from 15\% in R'Dat to 51\% in Ourika), the proportion of snowmelt in the total runoff is higher in the Rheraya and Ourika sub-catchments (up to $38 \%$ in 2004), than in the other sub-catchments. Figure 7 illustrates the cumulative curve of the computed daily snowmelt and rainfall proportions to the runoff in two distinct sub-catchments, Ourika and R'Dat, during the 2005 snowfall/snowmelt season. From the satellite imagery, snow can be

Table 7 Relative contribution of snowmelt and rainfall to streamflow.

\begin{tabular}{llll}
\hline & & Rainfall $(\%)$ & Snowmelt $(\%)$ \\
\hline Nfis & 2002 & 94.6 & 5.4 \\
& 2003 & 91.0 & 9.0 \\
& 2004 & 74.6 & 24.9 \\
\hline Rheraya & 2005 & 62.4 & 37.6 \\
& 2002 & 69.2 & 30.8 \\
& 2003 & 71.1 & 28.9 \\
& 2004 & 63.4 & 36.3 \\
\hline Ourika & 2005 & 51.4 & 48.6 \\
\hline Zat & 2002 & 75.3 & 24.7 \\
& 2003 & 48.6 & 51.4 \\
& 2004 & 61.9 & 37.7 \\
& 2005 & 51.0 & 49.0 \\
\hline R'Dat & 2002 & 93.6 & 6.4 \\
& 2003 & 78.6 & 21.4 \\
& 2004 & 84.7 & 14.8 \\
& 2005 & 55.9 & 44.1 \\
\hline
\end{tabular}
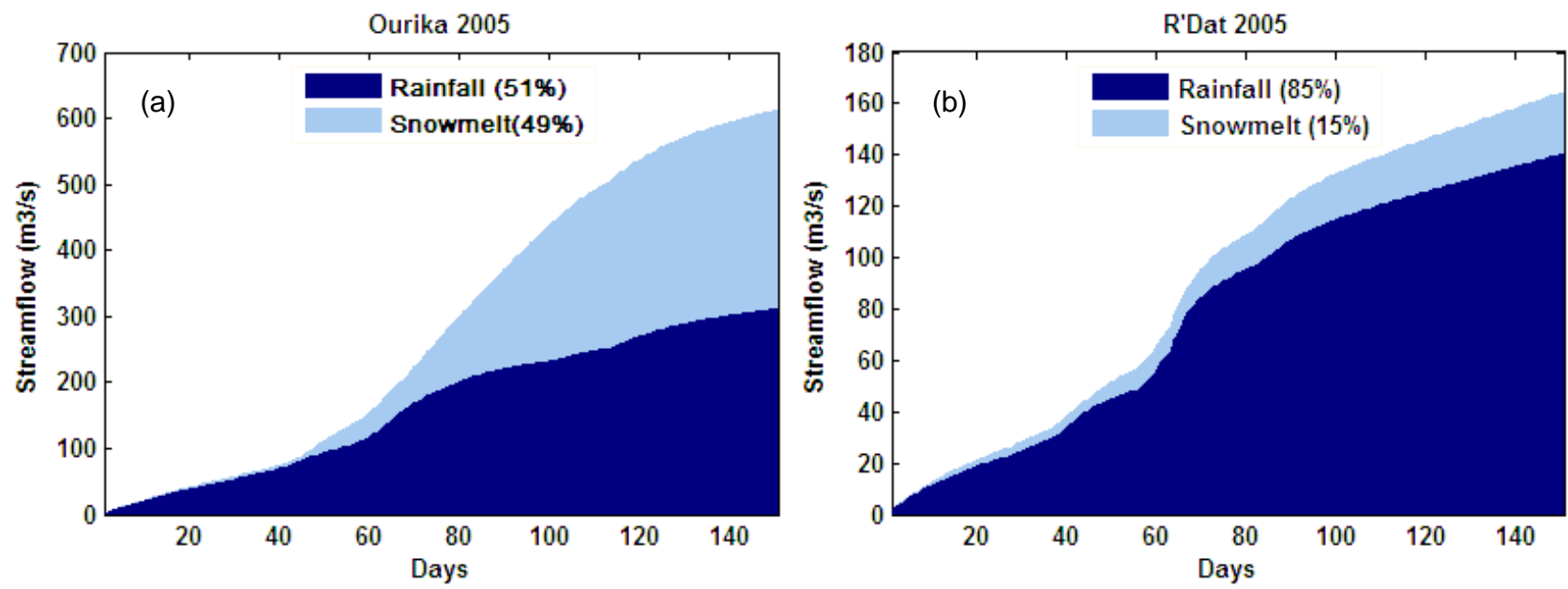

Fig. 7 Cumulative curves of snowmelt and rainfall contributions to streamflow for the 2005 snowfall/ snowmelt season in: (a) the Ourika sub-catchment, and (b) the R'Dat sub-catchment. 
observed each year above $1400 \mathrm{~m}$, but persists at altitudes above $2600 \mathrm{~m}$. According to the areaelevation curve for each sub-catchment (Fig. 2), this represents 18, 25, 40, 13 and 6\% of the Nfis, Rheraya, Ourika, Zat and R'Dat sub-catchments, respectively. Consequently, as expected, the mean snowmelt contribution is greater in the Ourika and Rheraya sub-catchments than in Nfis, Zat and R'Dat, respectively. Almost the whole snowmelt contribution to runoff occurs in February to May. Overall, between 2002 and 2005, this contribution is 25\%, on average.

\section{Model validation}

The model validation was conducted in the snowmelt season for 2002-2004 in the five sub catchments using representative SRM parameter values adopted for the calibration test. Figure 8 illustrates the daily runoff simulations using the two snow products MOD1 and MOD2, along with measured discharge values, and Table 6 summarizes the simulation result statistics for the five sub-catchments.
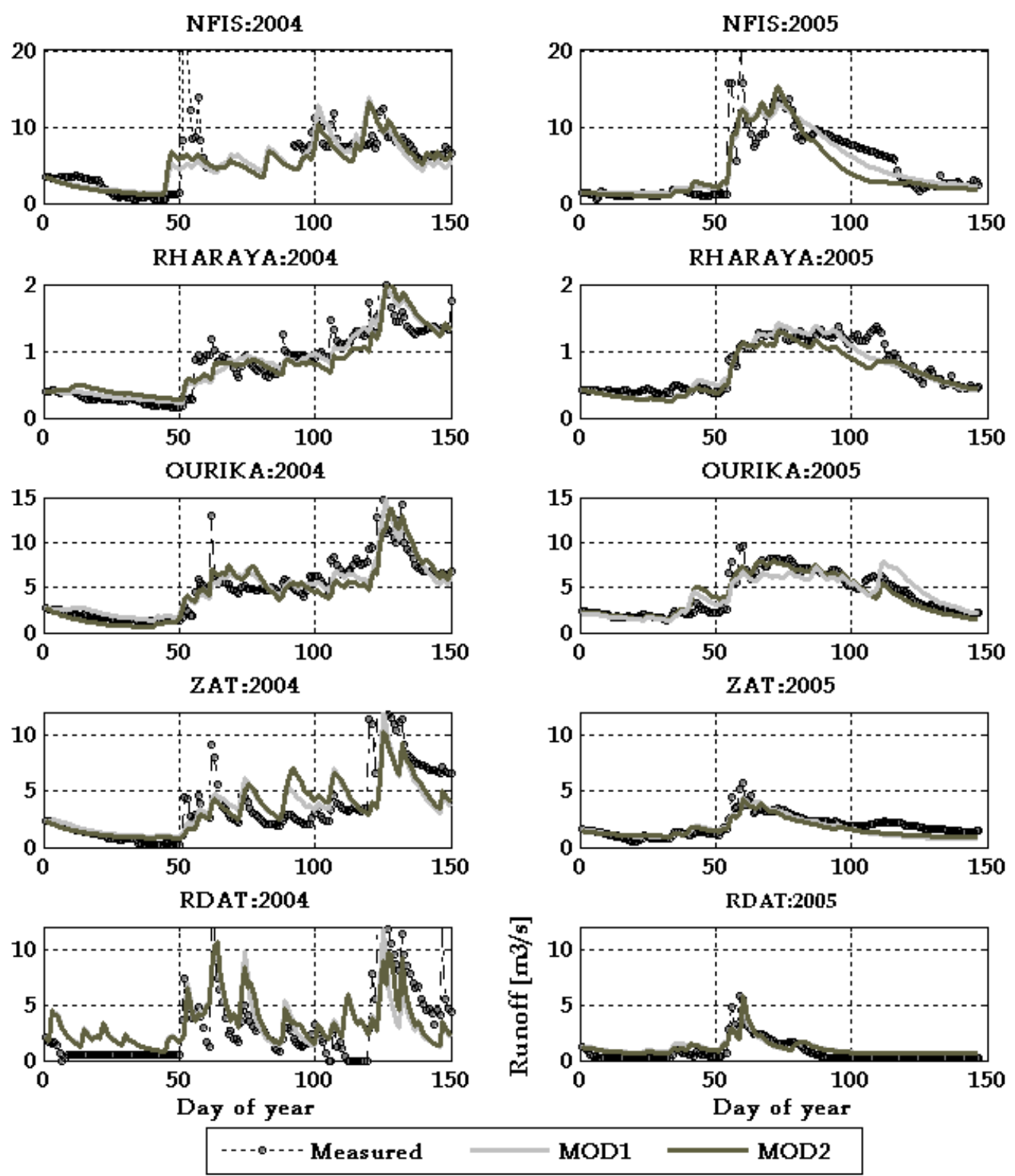

Fig. 8 Simulated and observed streamflows for the calibration and validation periods in the five subcatchments. 
At the seasonal scale, the streamflow simulations using the two snow products are comparable. The model efficiency with the two snow-covered area estimates varies widely from year to year and from one basin to another, reflecting the variation in climatic and topographic conditions of the region. In decreasing order, without taking into account the year 2003 when the model efficiency is very low for all sub-catchments, the streamflow simulations with MOD1 are good in Ourika and Rheraya $(E>0.72)$, acceptable in Zat $(E>0.50)$ where snowmelt contribution to runoff is significant, but poor in Nfis and RDat $(E>0.24)$. With MOD2, the model shows a good efficiency in $2004(E>0.72)$, acceptable in $2002(E=0.54)$ and poor in 2003. However, in the other sub-catchments, the performance of the model is acceptable for $2002(E>0.47)$ and lower in 2003 and 2004. The simulated average peak discharge was often lower than observed (example, peak after Day 60, in 2004, cf. Fig. 8). This can be explained by the local intense rainfall events that are not captured by the available raingauges. During recessions, the streamflow simulations are acceptable in all sub-catchments.

The inability of the model to simulate the daily runoff in Nfis, Rdat and Zat sub-catchments might be due to several factors. First, the spatio-temporal variability of the rainfall could not be captured with the available network. Local intense rainfall events occur mostly during the summer; however, patchy rainfall events during the winter might explain the poor prediction performance of peakflow discharge. This poor performance could be due to the model itself and has been reported in many other studies (Songweon et al., 2005; Xingong \& Williams, 2008). Second, streamflow measurement is a difficult task in the wadi bed: the gauging frequency (once a month on average) is not always adjusted for quickflow (high flow) occurrence, and wadi beds often undergo drastic modification after a storm, preventing discharge measurement when the scale is isolated or when the charge-discharge rating curve is no longer valid. This may result in runoff peaks being missed. This problem is less tricky during recessions and low flow with more stable daily runoff. Third, the runoff generation mechanisms during intense rainfall events in such an area, where streamflow tends to be dominated by rapid responses, are too complex for this relatively simple conceptual model. Fourth, in a semi-arid area, water losses via evapotranspiration for the vegetation and via sublimation for snow are important, but they are perhaps not properly taken into account by a simple conceptual model such as SRM. On the southern slopes of the High Atlas, Schulz \& de Jong (2004) found, with an energy balance model, that, on average, $44 \%$ of snow ablation was attributed to sublimation, and small pinnacles that could be due to sublimation (penitentes) were observed. Finally, the mechanisms of groundwater redistribution are also unrecognizable and are difficult to model (Duclaux, 2005; Chaponnière et al., 2008).

Finally, and more importantly, it must be stressed that if the performance at the seasonal scale is satisfactory for both the MOD1 and MOD2 SCA estimation methods, significant differences can be observed for selected storm/inter-storm events. This occurs when the raingauge network is too sparse to catch all precipitation events, or when errors in temperature estimates affect the rainfall/snowfall partition. In both cases the remote sensing method improves the short-term streamflow prediction. Figures 9 and 10 illustrate two cases of streamflow underestimation with MOD2, in the Ourika sub-catchment: from days 80 to 90 in 2002 (Fig. 9), due to missing rainfall events at the higher altitudes - in this period, the large SCA difference (about 30\%) translates into $20 \%$ of streamflow difference that remains up to three weeks; and from day 63 to 69 in 2005 (Fig. 10), in which underestimation is certainly due to incorrect temperature lapse rate. Because of the low redistribution of the snowmelt process, the difference in SCA during one week has an influence on streamflow for about three weeks.

\section{CONCLUSIONS}

The aim of the study was to investigate the relative performance of the Snowmelt Runoff Model (SRM) to simulate streamflow in five sub-catchments of the High Atlas Mountain range when using two snow extent products of limited precision: (a) snow-cover information derived from the VEGETATION sensor onboard the SPOT satellite with a mean weekly interval, and (b) snow- 


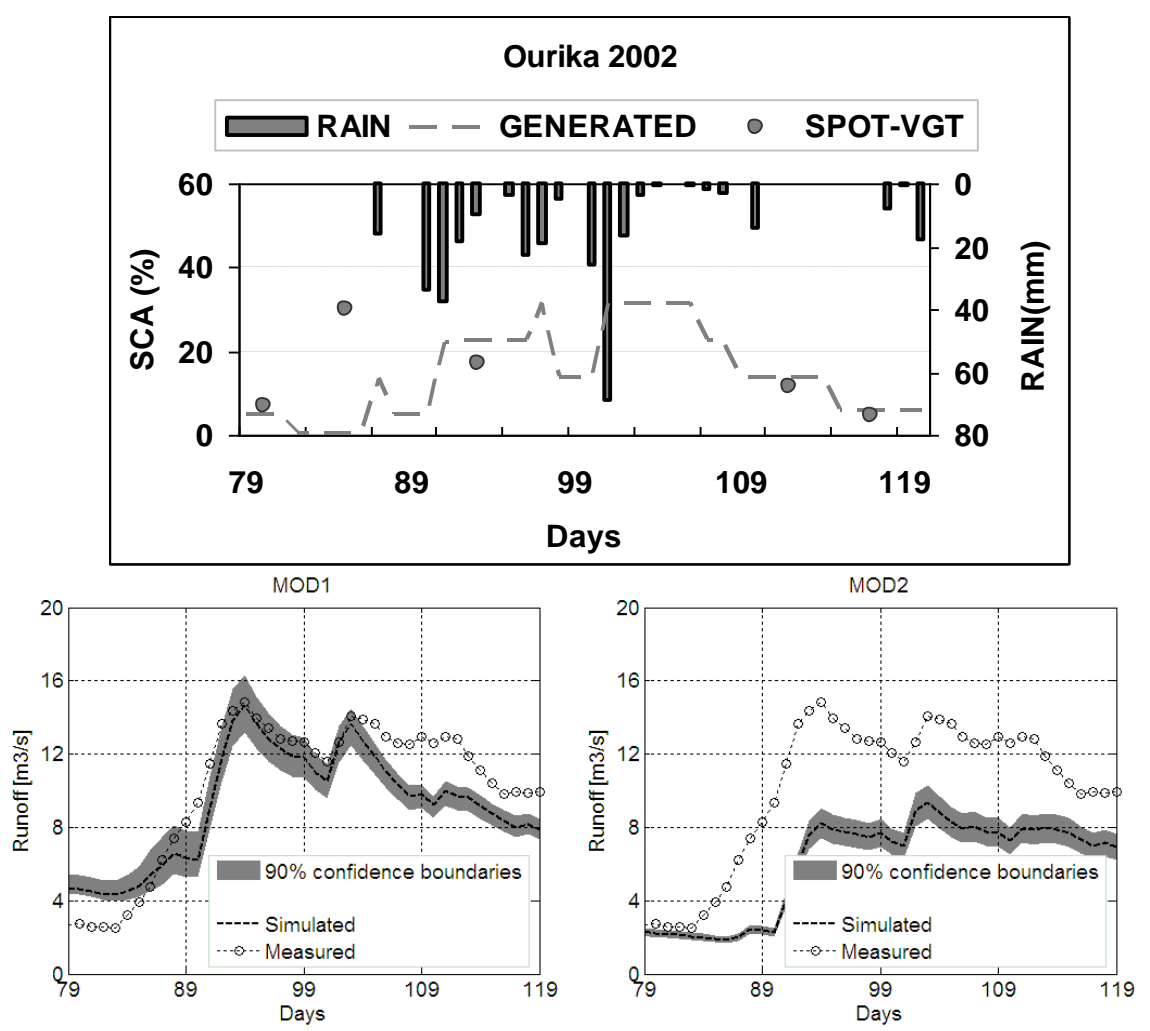

Fig. 9 Example of underestimation of streamflow by MOD2 when a rainfall event occurs only in the ungauged upper part of the Ourika sub-catchment in 2002.

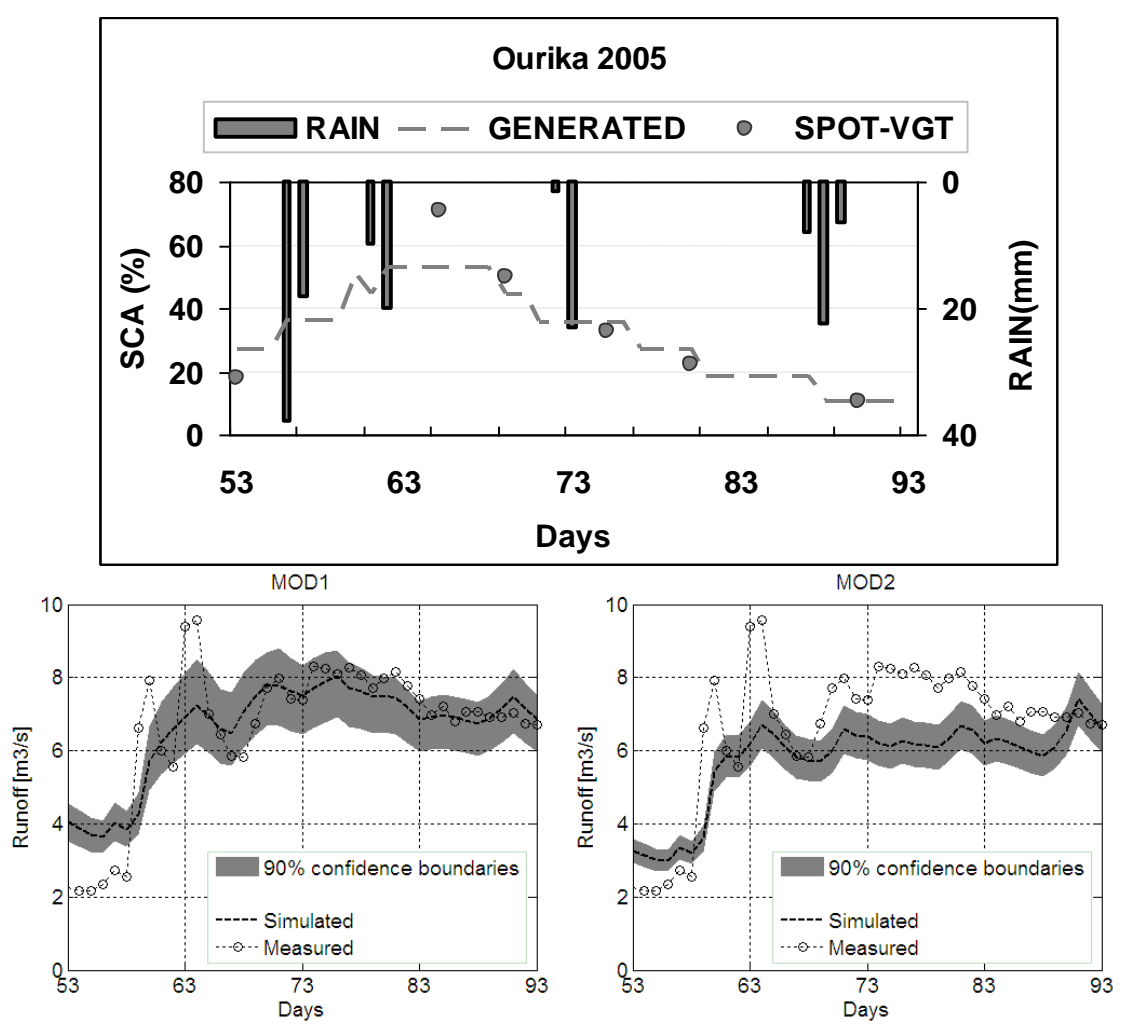

Fig. 10 Example of underestimation of streamflow by MOD2 caused by an underestimation of the SCA generated by the degree-day model in the Ourika sub-catchment in 2005. 
cover information computed solely from the meteorological data acquired at a few climate stations.

At the seasonal scale, snow-cover information obtained from SPOT-VEGETATION and generated with the degree-day method is quite comparable for the five tributary sub-catchments. In general, streamflow simulation is good in the Rheraya and Ourika sub-catchments where snow processes are significant and hydrometeorological data are relatively good. However, the SRM performances were poorer in the Nfis, Zat and R'Dat sub-catchments where snow plays a smaller role in the hydrological budget.

In this study, the snowmelt contribution to streamflow was computed in all sub-catchments from 2002 to 2005 using snow maps derived from the SPOT-VEGETATION sensor. Generally, it was shown that $25 \%$ of streamflow arriving from the northern sides of the High Atlas Mountains is derived from snowmelt.

At annual time scales, the simulated and observed hydrographs obtained using the two snow products in all sub-catchments are similar. Due to local intense rainfall events not measured by the weather stations, where streamflow tends to be dominated by rapid responses, the simulated multiple peak discharge was often lower than the observed value. During recessions, the streamflow simulations are acceptable. However, using snow-cover information derived from remotely sensed data can significantly improve streamflow prediction for individual inter-storm periods were rainfall events are not observed by the given network or when the temperature lapse rate is badly estimated.

Finally, the remote sensing and the meteorological data were used separately to compute snow-cover extent as input to the SRM model. Since the results with either data source are encouraging, combining both products to estimate the snowpack evolution between two image acquisitions (instead of linearly interpolated snow depletion curves, as it is classically done in most SRM applications) should improve the streamflow prediction performance in the High Atlas. This has not been tested in this study but will be done in the near future.

Acknowledgements This study was supported by the research projects SUDMED (IRD-UCAM), PAI (Programme d'Action Intégrée du Comite Mixte Interuniversitaire Franco-Marocain, Jeune Equipe IRD, CREMAS), Volubilis (MA/06/148) and the PLEADeS Project (http://www.pleiades.es/) funded by the European Commission (Sixth PCRD). The authors are grateful to ABHT (Agence du Bassin hydraulique de Tensift, Marrakech, Morocco) for the acquisition of the hydro-meteorological data on the Tensift watersheds. We also thank the SPOTVEGETATION programme for providing the series of satellites images.

\section{REFERENCES}

Andreadis, K. M. \& Lettenmaier, D. P. (2006) Assimilating remotely sensed snow observations into a macroscale hydrology model. Adv. Water Resour. 29, 872-886.

Bergstrom, S. (1975) The development of a snow routine for the HBV-2 model. Nordic Hydrol. 6, 73-92.

Beven, K. J. (1993) Prophecy, reality and uncertainty in distributed hydrological modelling. Adv. Water Resour. 16, 41-51.

Beven, K. J. (2008) Environmental Modelling: An Uncertain Future? Routledge, London, UK.

Beven, K. \& Binley, A. (1992) the future of distributed models: model calibration and uncertainty prediction. Hydrol. Processes 6, 279-298.

Boudhar, A., Duchemin, B., Hanich, L., Chaponnière, A., Maisongrande, P., Boulet, G., Stitou, J. \& Chehbouni, A. (2007) Snow covers dynamics analysis in the Moroccan High Atlas using SPOT-VEGETATION data. Sécheresse 18(4), 278-88.

Brasnett, B. (1999) A global analysis of snow depth for numerical weather prediction. J. Appl. Met. 38, 726-740.

Ceballos-Barbancho, A., Morán-Tejeda, E.,Luengo-Ugidos, M. A. \& Llorente-Pinto, J. M. (2008) Water resources and environmental change in a Mediterranean environment: the south-west sector of the Duero River basin (Spain). J. Hydrol. 351, 126-138.

Chaponnière, A., Maisongrande, P., Duchemin, B., Hanich, L., Boulet, G., Halouat, S. \& Escadafal, R. (2005) A combined high and low spatial resolution approach for mapping snow covered area in the Atlas Mountain. Int. J. Remote Sens. 26, 2755-2777.

Chaponnière, A., Boulet, G., Chehbouni, A. \& Aresmouk, M. (2008) Understanding hydrological processes with scarce data in a mountain environment. Hydrol. Processes 22, 1908-1921. 
Chehbouni, A., Escadafal, R., Boulet, G., Duchemin, B., Simonneaux, V., Dedieu, G., Mougenot, B., Khabba, S., Kharrou, H., Merlin, O., Chaponnière, A., Ezzahar, J., Erraki, S., Hoedjes, J., Hadria, R., Abourida, H., Cheggour, A., Raibi, F., Boudhar, A., Hanich, L.,Guemouria, N., chehbouni, Ah., Olioso, A., Jacob, F. \& Sobrino, J. (2008) An integrated modelling and remote sensing approach for hydrological study in semi-arid regions: the SUDMED Program. Int. J. Remote Sens. 29, 5161-5181.

Clark, M. P., Slater, A. G., Barrett, A. P., Hay L. E., McCabe, G. J., Rajagopalan, B. \& Leavesley G. H. (2006) Assimilation of snow covered area information into hydrologic and land surface models. Adv. Water Resour. 29, 1209-1221.

Clyde, G D. (1931) Snow melting characteristics. Utah Agricultural Experiment Station Bull. 231, 1-23.

Collins, E. H. (1934) Relationship of degree-days above freezing to runoff. Trans. Am. Geophys. Union, Reports and Papers, Hydrology, 15, 624-629.

Cudennec, C., Leduc, C. \& Koutsoyiannis, D. (2007) Dryland hydrology in Mediterranean regions-a review. Hydrol. Sci. J., 52(6), 1077-1087.

Dozier, J. (1989) Spectral Signature of Alpine Snow Cover from the Landsat Thematic Mapper. Remote Sens. Environ. 28, $9-22$.

Duclaux, A. (2005) Modélisation hydrologique de cinq bassins versants du Haut-Atlas Marocain avec SWAT (Soil and Water Assessment Tool). Master's Thesis, Institut National Agronomique de Paris-Grignon, France.

Flerchinger, G. N. \& Cooley, K. R. (2000) A ten-year water balance of a mountainous semi arid watershed. J. Hydrol. 237, 86-99.

Gomez, L. \& Rango, A. (2002) Operational snowmelt runoff forecasting in the Spanish Pyrenees using the snowmelt runoff model. Hydrol. Processes 16, 1583-1591.

Hall, D. K., Riggs, G. A, Salomonson, V. V., Digirolamo, D. G. \& Bayr, K. J. (2002) MODIS snow-cover products. Remote Sens. Environ. 83, 181-194.

Hanich, L., de Solan, B., Duchemin, B., Maisongrande, P., Chaponnière, A., Boulet,G. \& Chehbouni, G. (2003) Snow cover mapping using SPOT-VEGETATION with high resolution data: application in the Moroccan Atlas Mountains. In: Proc. IEEE Int. Geoscience and Remote Sensing Symposium (IGARSS) (21-25 July 2003, Toulouse, France). [Please provide publisher details; and editor(s) if known]

Jesko, S., Martinec, J. \& Klaus, S. (1999) Distributed mapping of snow and glaciers for improved runoff modelling. Hydrol. Processes 13, 2023-2031.

Khazaei, E., Spink, A. E. F. \& Warner, J. W. (2003) A catchment water balance model for estimating groundwater recharge in arid and semi-arid regions of south-east Iran. Hydrogeol. J. 11(3), 333-342.

Klaus, S. (1998) Effects of climate change on water resources and runoff in an Alpine basin. Hydrol. Processes 12, 1659-1669.

Leroux, J. (2006) Optical remote sensing of snow cover dynamics in the High-Atlas mountains of Morocco: application to the hydrological modelling of the Rheraya sub-catchment. Master Thesis in "Radio Astronomy and Space Science", Chalmers University of Technology, Göteborg, Sweden..

Maisongrande, P., Duchemin, B. \& Dedieu, G. (2004) VEGETATION/SPOT-An Operational Mission for the Earth Monitoring: Presentation of New Standard Products. Int. J. Remote Sens. 25, 9-14.

Makhlouf, Z. (1994). Compléments sur le modèle pluie-débit GR4J et essai d'estimation de ses paramètres. PhD Thesis, Université Paris-Sud / CEMAGREF Antony, Division Hydrologie, France.

Martinec, J. (1960) The degree-day factor for snowmelt runoff forecasting. In: IUGG General Assembly of Helsinki, IAHS Commission of Surface Waters, 468-477. IAHS Publ. 51, IAHS Press, Wallingford, UK. Available at: http://iahs.info/redbooks/051.htm.

Martinec, J. (1975) Snowmelt-runoff model for stream flow forecasts. Nordic Hydrol. 6, 145-154

Martinec, J. (1985) Snowmelt runoff models for operational forecasts. Nordic Hydrol. 16, 129-136.

Martinec, J. \& Rango, A. (1995) Seasonal runoff forecasts for hydropower based on remote sensing. In: Proc. 63rd Western Snow Conference (Reno, Nevada, USA), 10-20. [Please provide publisher details; and editor(s) if known]

Martinec, J., Rango, A. \& Robert R. (2005) Snow Runoff Model (SRM) User's Manual. http://hydrolab.arsusda.gov/cgibin/srmhome [Accessed: January 2005].

Matson, M. (1991) NOAA satellite snow cover data. Palaeogeogr. Paleoecol. 90, 213-218.

Matthews, D. A. (1989) Programme Al Ghait-Morocco winter Snowpack Augmentation Project. Final report. Department of the Interior, Washington DC, USA.

McLaughlin, D. (1995) Recent advances in hydrologic data assimilation, US Nat. Report, IUGG 1991-1994. Rev Geophys. 33, 977-84.

McLaughlin, D., O'Neill, A., Derber, J. \& Kamachi, M. (2005) Opportunities for enhanced collaboration within the data assimilation community. Quart. J. Roy. Met. Soc. 131, 3683-3693.

Mitchell, K. M. \& DeWalle, D. R. (1998) Application of the snowmelt runoff model using multiple-parameter landscape zones on the Towanda Creek basin, Pennsylvania. J. Am. Water Resour. Assoc. 34, 335-346.

Nagler, T., Rott, H., Malcher, P., Müller, F.. (2008) Assimilation of meteorological and remote sensing data for snowmelt runoff forecasting. Remote Sens. Environ. 112(4), 1408-1420.

Nash, J. E. \& Sutcliffe, J. V. (1970) River flow forecasting through conceptual models, Part 1-A discussion of principles. J. Hydrol. 10(3), 282-290.

Pitlick, J. (1994) Relation between peak floods, precipitation and physiography for five mountainous regions in the western USA. J. Hydrol. 158(3-4), 219-240.

Rango, A. \& Martinec, J. (1979) Application of a snowmelt-runoff model using Landsat data. Nordic Hydrol. 10, $225-238$.

Rango, A. \& Martinec, J. (1981) Accuracy of snowmelt runoff simulation. Nordic Hydrol. 12, 265-274.

Rango, A. \& Martinec, J. (1995) Revisiting the degree-day method for snowmelt computations. Water Resour. Bull. 31, $657-669$

Rango, A. \& Martinec, J. (1997) Water storage in mountain basins from satellite snow cover mapping. In: Remote Sensing and Geographical Information Systems for Design and Operation for Water Resources System (ed. by M. F. Baumgartner, G. A. Schultz \& A. I. Johnson), 83-91. IAHS Publ. 242. IAHS Press, Wallingford, UK

Rango, A. \& van Katwijk, V. (1990) Development and testing of a snowmelt-runoff forecasting technique. Water Resour. Bull. 
26, 135-144.

Rodriguez, J. Y. (1994) an operational forecasting snowmelt model with objective calibration. Nordic Hydrol. 25, 79-100.

Schulz, O. \& de Jong, C. (2004) Snowmelt and sublimation: field experiments and modelling in the High Atlas Mountains of Morocco. Hydrol. Earth System Sci. 8, 1076-1089.

Seo, D., Koren, V. \& Cajina, N. (2003) Real-time variational assimilation of hydrologic and hydrometeorological data into operational hydrologic forecasting. J. Hydromet. 4, 627-641.

Shafer, B. A., Jones, E. B. \& Frick, D. M. (1982) Snowmelt runoff simulation using the Martinec Rango model on the South Fork Rio Grande and Conejos River in Colorado. AgRISTARS Report CP-G1-04072, Goddard Space Flight Center, Greenbelt, Maryland, USA.

Slater, A. G. \& Clark, M. P. (2006) Snow data assimilation via an ensemble Kalman filter. J. Hydromet. 7, 478-493.

Songweon, L., Andrew, G. K. \& Thomas, M. O. (2005) a comparison of MODIS and NOHRSC snow-cover products for simulating streamflow using the Snowmelt Runoff Model. Hydrol. Processes 19, 2951-2972.

Sun, C., Walker, J. P. \& Houser, P. R. (2004) A methodology for snow data assimilation in a land surface model. J. Geophys. Res. 109, D08108. doi:10.1029/2003JD003765.

Viviroli, D., Weingartner, R. \& Messerli, B. (2003) Assessing the hydrological significance of the world's mountains. Mountain Res. Develop. 23, 32-40.

Xingong, L. \& Williams, M. W. (2008) Snowmelt runoff modelling in an arid mountain watershed,Tarim Basin, China. Hydrol. Processes 22, 3931-3940.

\section{Received 29 October 2008; accepted 19 June 2009}

Final length estimated at 20 pages. 8 excess pages at $50 \mathrm{GBP}$ each $=£ 400$ to pay 